\title{
The imbalance of investment activities
}

\author{
Svetlana Lobova ${ }^{1, *}$ Aleksei Bogoviz ${ }^{2}$, and Julia Ragulina ${ }^{2}$ \\ ${ }^{1}$ Altai State University, 656049, Lenin ave., 61, Barnaul, Russia \\ ${ }^{2}$ Federal Research Center of Agrarian Economy and Social Development of Rural Areas - All \\ Russian Research Institute of Agricultural Economics, 123007, Khoroshevskoye shosse, 35k2, \\ Moscow, Russia
}

\begin{abstract}
The state of the economic system is characterized by a group of economic indicators that are structural ones, reflecting certain aspects of reproduction, including investment. The purpose of this research is to reveal the level of imbalance in the investment activity by the main types of activity, the adjustment of which will promote effective interaction of economic sectors and economic growth. The level of imbalance is defined as the variance in the deviation of sectoral indicators from the average for the economy, which we consider to be optimal. The analysis allowed making the following conclusions: the greatest structural shift is observed in terms of the share of investments in the active part of fixed assets and long-term financial investments; uneven support is provided from the federal budget to different branches; the investment activity is close in characteristics to the average values for the country and varies up to $8.16 \%$ in most industries. The imbalance in investment activity is determined not only by the implementation of the state sectoral programs and by investing priority sectors from the budget, but also by the differences in the conditions for its formation.
\end{abstract}

\section{Introduction}

In 2017, Russia's industries began to gradually come out of the crisis, characterized by a decline in the investment activity and a decrease in the investment attractiveness. The influence of individual industries on the economic growth is determined by the level of economic development. Structural imbalance is one of the features of the investment process in Russia. This hinders the economic growth, since the balance creates the conditions for the formation of investment activity and effective interaction of the sectors of economy. Identification of the imbalance in the investment activity will make it possible to characterize the directions of its changes taking into account the financial and economic processes at the sectoral level.

The imbalance of the state of the sectors of the economic complex and the modern requirements of innovative and investment development leads to the fact that ensuring a balanced development of the investment activity in the sectors is the urgent task.

\footnotetext{
* Corresponding author: barnaulhome@ mail.ru
} 


\section{Methods}

The state of the economic system is characterized by a group of economic indicators that are structural ones, reflecting certain aspects of reproduction, including investment. These are structural changes in the economy that lie, first of all, at the heart of the sectoral differences. Hence is the relevance of the problem of studying the influence of structural components and their regulation on the efficiency of sectoral development. Therefore, a methodical approach to assessing structural changes was used to evaluate the investment activity and its impact on the economic growth.

To assess the imbalance of indicators and processes, it is possible to use variances. Thus, D. Rodrik [5] analyzed the structure of national economies of 10 developed countries from the average value. The variance of the indicators' deviation was $2 \%$, so the average indicator was considered as optimal. The parameters of the structural imbalance of the economy by the variance of certain indicators were calculated in the studies of N.M. Abdikeev and Yu.S. Bogachev [3] and their stability were estimated.

To identify the role of industries in the investment development, we have identified the indicators of volatility of the investment activity (as a variance of indicators) for the main types of activity, as well as the conditions for its formation. Data from the Federal State Statistics Service of the Russian Federation [1, 2], which characterize investment activity, became the initial data for the calculations.

\section{Results}

Investments in fixed assets include not only expenses aimed at the construction, reconstruction of facilities, the acquisition of machinery, equipment, vehicles, production and economic equipment, the formation of a working, productive and breeding herd, planting and cultivating perennial crops, but also investments in intellectual property objects: works of science, literature and art; software and databases for computers, inventions, utility models, industrial designs, selection achievements, manufactured intangible search costs, costs for research, development and technological work, etc. [2]. The distribution of investments in fixed assets by types of economic activity is carried out in accordance with the All-Russian classifier of economic activities (ACTEC).

The result of investment activity is the economic growth - the expanded reproduction. The level of the expanded reproduction is defined as the ratio of investment in fixed assets to depreciation of fixed assets by types of economic activity (Table 1). By types of activity, the level of the expanded reproduction in such types of activities as "construction", "transport and communications", "agriculture, hunting and forestry" is higher than the average for the economy.

To measure the sectoral imbalance in investment activity, the variance indicator was used. The variance calculation was performed for individual types of activity and for the indicators of investment activity.

The greatest structural shift is observed in the share of investment in the active part of fixed assets - machinery, equipment, vehicles and long-term financial investments. Uneven support is provided to different branches from the federal budget. Investment activity is close in its characteristics to the average values for the country as a whole and varies up to $8.16 \%$ of the average values for such activities as "agriculture, hunting and forestry", "construction", "transport and communications", "production and distribution of electricity, gas and water". The greatest deviation in the investment activity is in "fishing, fish farming".

Table 1. Estimation of the level of extended reproduction by types of economic activity. 


\begin{tabular}{|c|c|c|c|c|c|c|c|}
\hline \multirow[t]{2}{*}{$\begin{array}{l}\text { Types of } \\
\text { economic } \\
\text { activity }\end{array}$} & \multicolumn{2}{|c|}{$\begin{array}{l}\text { Investments in } \\
\text { fixed assets, } \\
\text { billion rubles }\end{array}$} & \multicolumn{2}{|c|}{$\begin{array}{c}\text { Amortization of fixed } \\
\text { assets of commercial } \\
\text { organizations by types } \\
\text { of economic activity, } \\
\text { million rubles }\end{array}$} & \multicolumn{2}{|c|}{$\begin{array}{l}\text { The level of } \\
\text { extended } \\
\text { reproduction }\end{array}$} & \multirow[t]{2}{*}{$\begin{array}{l}\text { The index of } \\
\text { the level of } \\
\text { extended } \\
\text { reproduction, } \\
2016 \text { to } \\
2015, \%\end{array}$} \\
\hline & 2015 & 2016 & 2015 & 2016 & 2015 & 2016 & \\
\hline $\begin{array}{l}\text { Economy as a } \\
\text { whole }\end{array}$ & 10742.3 & 14639.8 & 5297691.3 & 5860652.0 & 2.03 & 2.50 & 123.19 \\
\hline \multicolumn{8}{|l|}{$\begin{array}{l}\text { by main } \\
\text { economic } \\
\text { activities }\end{array}$} \\
\hline $\begin{array}{l}\text { agriculture, } \\
\text { hunting and } \\
\text { forestry }\end{array}$ & 505.8 & 611.2 & 164596.8 & 180929.6 & 3.07 & 3.38 & 109.93 \\
\hline $\begin{array}{l}\text { fishing, fish } \\
\text { farming }\end{array}$ & 14.4 & 16.4 & 5483.2 & 7025.5 & 2.63 & 2.33 & 88.89 \\
\hline mining & 2385.2 & 2830.4 & 1181380 & 1341114.3 & 2.02 & 2.11 & 104.53 \\
\hline $\begin{array}{l}\text { processing } \\
\text { industries }\end{array}$ & 2172.6 & 2123.7 & 1039223.5 & 1136467.8 & 2.09 & 1.87 & 89.39 \\
\hline $\begin{array}{l}\text { production and } \\
\text { distribution of } \\
\text { electricity, gas } \\
\text { and water }\end{array}$ & 980.0 & 940.2 & 528934.9 & 604410.1 & 1.85 & 1.56 & 83.96 \\
\hline construction & 401.2 & 445.0 & 99585.3 & 97931.0 & 4.03 & 4.54 & 112.79 \\
\hline $\begin{array}{l}\text { wholesale and } \\
\text { retail trade; } \\
\text { repair of motor } \\
\text { vehicles, } \\
\text { motorcycles, } \\
\text { household goods } \\
\text { and personal } \\
\text { items }\end{array}$ & 542.8 & 632.7 & 705193.5 & 769046.5 & 0.77 & 0.82 & 106.88 \\
\hline $\begin{array}{l}\text { transport and } \\
\text { communications }\end{array}$ & 2499.7 & 2726.7 & 857342.4 & 924915.7 & 2.92 & 2.95 & 101.11 \\
\hline communications & 356.1 & 384.2 & 245845.6 & 269815.7 & 1.45 & 1.42 & 98.31 \\
\hline
\end{tabular}

Calculated by the author according to data [2]. 
Table 3. Evaluation of imbalance in investment activity.

\begin{tabular}{|c|c|c|c|c|c|c|c|c|c|c|c|}
\hline \multirow[b]{2}{*}{$\begin{array}{l}\text { Investment } \\
\text { activity }\end{array}$} & \multirow[b]{2}{*}{ 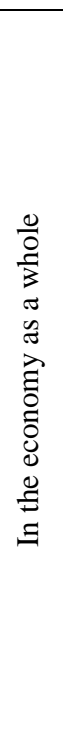 } & \multicolumn{9}{|c|}{ By main types of economic activity } & \multirow[b]{2}{*}{ 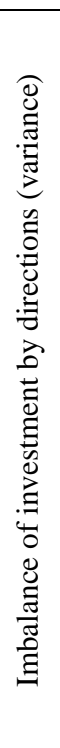 } \\
\hline & & $\begin{array}{l}\text { D } \\
0 \\
0 \\
0 \\
0 \\
0 \\
0 \\
0 \\
0 \\
0 \\
0 \\
0 \\
0 \\
0 \\
0 \\
0 \\
0 \\
0 \\
0\end{array}$ & 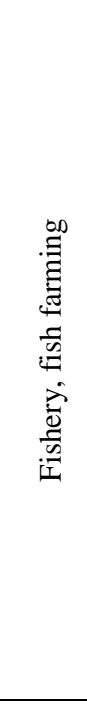 & $\begin{array}{l}\stackrel{0}{\Xi} \\
\stackrel{\Xi}{\Xi}\end{array}$ & 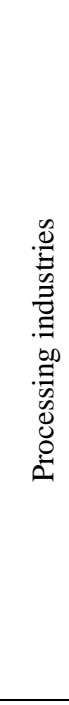 & 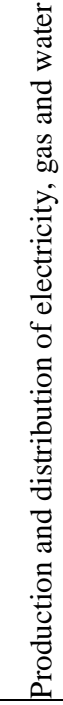 & 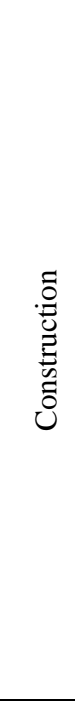 & 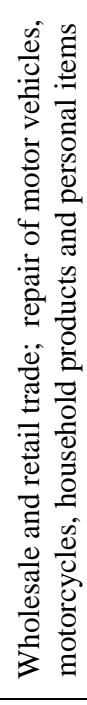 & 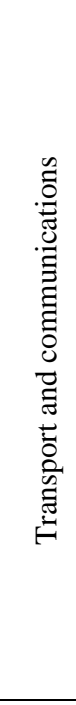 & 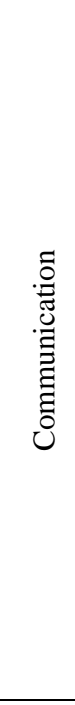 & \\
\hline $\begin{array}{l}\text { The share of } \\
\text { long-term } \\
\text { financial } \\
\text { investments of } \\
\text { organizations, as } \\
\text { a percentage of } \\
\text { the total }\end{array}$ & 11.3 & 13.1 & 54.2 & 37.7 & 17.3 & 6.9 & 3.4 & 8.9 & 17.2 & 38.8 & 19.5 \\
\hline $\begin{array}{l}5 \text { Index of } \\
\text { physical volume } \\
\text { of investments in } \\
\text { fixed assets, in } \\
\text { percentage to the } \\
\text { previous year (in } \\
\text { comparable } \\
\text { prices) }\end{array}$ & 99.1 & 113.3 & 102.6 & 114.4 & 90.2 & 89.1 & 103.9 & 108.2 & 101.3 & 98.5 & 9.0 \\
\hline $\begin{array}{l}\text { Share of } \\
\text { investments in } \\
\text { fixed assets in } \\
\text { total investment } \\
\text { in the economy, } \\
\text { in percent }\end{array}$ & 8.13 & 4.2 & 0.1 & 19.4 & 14.6 & 6.4 & 3.0 & 4.3 & 18.6 & 2.6 & 6.9 \\
\hline $\begin{array}{l}\text { Share of } \\
\text { investment in } \\
\text { machinery, } \\
\text { equipment, } \\
\text { vehicles, in } \\
\text { percent }\end{array}$ & 30.6 & 41.0 & 95.2 & 18.1 & 56.4 & 38.3 & 14.4 & 53.7 & 40.4 & 63.0 & 28.1 \\
\hline $\begin{array}{l}\text { Share of } \\
\text { investments in } \\
\text { fixed assets } \\
\text { financed from the } \\
\text { federal budget }\end{array}$ & 9.3 & 2.3 & 0.9 & 0.0 & 1.6 & 4.4 & 14.3 & 0.2 & 19.6 & 3.5 & 7.7 \\
\hline
\end{tabular}




\begin{tabular}{|c|c|c|c|c|c|c|c|c|c|c|c|}
\hline $\begin{array}{l}\text { Share of } \\
\text { investments in } \\
\text { fixed assets } \\
\text { financed from the } \\
\text { budgets of the } \\
\text { constituent } \\
\text { entities of the } \\
\text { Russian } \\
\text { Federation }\end{array}$ & 6.0 & 1.3 & 0.0 & 0.0 & 0.1 & 4.0 & 6.6 & 0.0 & 11.9 & 0.2 & 5.1 \\
\hline $\begin{array}{l}\text { Imbalance of } \\
\text { investment by } \\
\text { types of activity } \\
\text { (variance) }\end{array}$ & 0 & 8.16 & 32.14 & 14.93 & 12.36 & 5.91 & 8.16 & 11.22 & 8.02 & 17.81 & - \\
\hline
\end{tabular}

Calculated by the author according to data [2].

\section{Discussion}

The imbalance of the investment activity by types of activity is determined not only by the implementation of the state sectoral programs and by investing priority sectors from the budget, but also by the differences in the conditions for its formation.

Conditions for the formation of the investment activities contribute to the achievement of the necessary investment tasks. The most favorable conditions for the formation of the investment activity are in fishery and fish farming (Table 2). In comparison with other activities, the number of profitable organizations is much higher here, as well as the level of profitability of sales and assets, and the level of crediting is lower.

Table 2. Summary characteristics of the conditions and results of investment activities.

\begin{tabular}{|c|c|c|c|c|c|c|c|c|c|c|}
\hline \multirow[b]{2}{*}{$\begin{array}{l}\text { Conditions for the } \\
\text { formation of } \\
\text { investment } \\
\text { activities }\end{array}$} & \multirow[b]{2}{*}{ 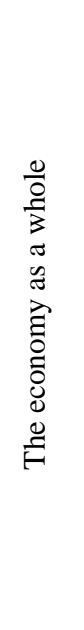 } & \multicolumn{9}{|c|}{ Including sectors } \\
\hline & & 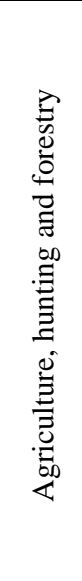 & 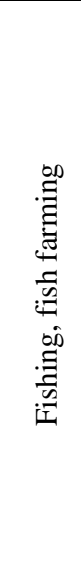 & 咅 & 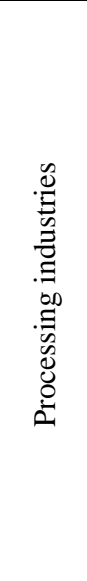 & 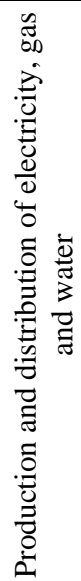 & 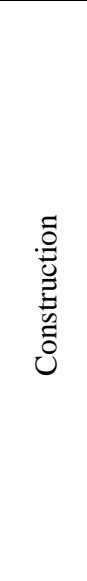 & 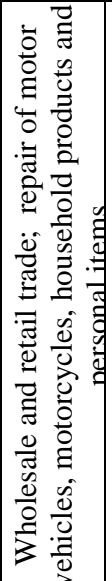 & 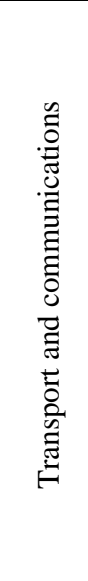 & 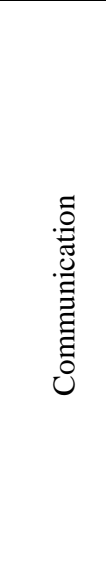 \\
\hline $\begin{array}{l}\text { Index of work, } \\
\text { services, to the } \\
\text { previous year,\%* }\end{array}$ & 103.4 & 104.8 & - & 102.5 & 100.1 & 101.5 & 97.8 & $99.0 * *$ & 101.8 & 96.2 \\
\hline $\begin{array}{l}\text { Producer price } \\
\text { index (tariffs), by } \\
\text { the previous } \\
\text { year, } \%\end{array}$ & 107.4 & 101.8 & 103.3 & 107.9 & 107.7 & 105.1 & 103.2 & 105.6 & 105.6 & $105.4^{* * *}$ \\
\hline
\end{tabular}




\begin{tabular}{|c|c|c|c|c|c|c|c|c|c|c|}
\hline $\begin{array}{l}\text { Average number } \\
\text { of employees, } \\
\text { thousand people }\end{array}$ & 72400 & 1547.4 & 56.1 & 943.0 & 7032.5 & 1743.7 & 2455.4 & 5709.5 & 3685.8 & 720.0 \\
\hline $\begin{array}{l}\text { Average monthly } \\
\text { nominal accrued } \\
\text { wages of } \\
\text { employees, rubles }\end{array}$ & 30738.4 & 21755 & 54927 & 69936 & 34592 & 39629 & 32332 & 30030 & 41510 & 37984 \\
\hline $\begin{array}{l}\text { Balanced financial } \\
\text { result (profit } \\
\text { minus loss) of } \\
\text { organizations, bln } \\
\text { rubles }\end{array}$ & 12801.6 & 246.8 & 85.1 & 2134.2 & 3066.7 & 738.3 & 39.8 & 2517.6 & 1126.5 & 211.1 \\
\hline $\begin{array}{l}\text { Profitability of } \\
\text { goods sold, } \\
\text { products (works, } \\
\text { services),\% }\end{array}$ & 7.6 & 15.7 & 54.5 & 26.2 & 10.1 & 7.1 & 4.2 & 4.8 & 10.1 & 16.6 \\
\hline $\begin{array}{l}\text { Return on } \\
\text { assets, \% }\end{array}$ & 5,9 & 6,0 & 26,9 & 9,9 & 6,3 & 5,3 & 0,4 & 6,5 & 5,2 & 6,8 \\
\hline $\begin{array}{l}\text { Share of profitable } \\
\text { organizations, } \%\end{array}$ & 70.5 & 76.7 & 77.0 & 61.0 & 73.9 & 52.6 & 68.9 & 77.9 & 66.8 & 70.0 \\
\hline $\begin{array}{l}\text { Share of loss- } \\
\text { making } \\
\text { organizations, \% }\end{array}$ & 29.5 & 23.3 & 23.0 & 39.0 & 26.1 & 47.4 & 31.1 & 22.1 & 33.2 & 30.0 \\
\hline $\begin{array}{l}\text { Share of } \\
\text { organizations that } \\
\text { had overdue } \\
\text { accounts } \\
\text { payable, } \%\end{array}$ & 14.7 & 14.0 & 9.4 & 28.2 & 16.6 & 44.7 & 15.3 & 4.9 & 16.7 & 10.8 \\
\hline
\end{tabular}

** - For certain types of activity, the indicator corresponding to this sector is shown (turnover of trade, freight turnover of transport, volume of communication services, etc.)

** - Average value of the indices of turnover for the wholesale and retail trade

$* * *$ - average value of tariff indices for legal entities and individuals

Compiled from data [1].

The largest growth of production is demonstrated by agriculture with a slight increase in producer prices. Profitability indicators and the number of profitable organizations are also above average.

\section{Conclusion}

The carried out analysis of the imbalance of the investment activity by types of activity showed that the disproportions in the investment development of industries are caused by budgetary, debt and investment issues. Their solution requires the search for new institutional, infrastructural and political decisions that can attract investors to the sectors of the economy.

\section{References}

1. Federal Service of State Statistics, Investment activity in Russia: conditions, factors, trends (FSSS, Moscow, 2017)

2. Rosstat, Investments in Russia (Rosstat, Moscow, 2017)

3. N. M. Abdikeev, Yu. S. Bogachev, Vestnik Phinansovogo Universiteta, 21, 3 (2017) 
4. T. C. Devezas, Kondratieff waves, warfare and world Security (IOS Press, Amsterdam, 2006)

5. D. Rodrik, Normalizing industrial policy (World Bank, Washington, 2008) 